\title{
THEORETICAL FRAMEWORK OF VEGA 1/1243/04 RESEARCH: INTERPERSONAL INTERVIEWS AND MOTIVATION
}

This paper is a result of the research project VEGA No. 1/1243/04 "Highly-educated human potential management and development". It deals with the importance of basic types of interviews used in human potential management and development. It presents and argues the results of a selective, orientation, appraisal and exit interview. It highlights positive and negative aspects of these types of interviews. It confirms that managers and staff from personnel departments can enhance their perception of these interview techniques. It must be borne in mind and remembered that there is always a very strong motivational accent in these interviews.

Keywords: motivation, motivational accent, interview, managers, process, skill

\section{Introduction}

In many organizations, the real work and out-of-work environment places very high requirements and standards on employees as well as managers. The phenomenon, which repeatedly assists individuals and groups to successfully cope with these requirements, is their motivation. Motivation, as a constantly nurtured inner process, by which individuals define, revalue and fulfil their aims, needs, aspirations, wishes and expectations. It is, however, quite often weakened by many negative situations and experiences. According to this knowledge, it is necessary for managers, experts and organization employees to continuously reinforce their own motivation levels as well as the motivation of their subordinates, superiors and organizationally equal co-workers. The reason of this intent interest is the fact that the motivation of employees and management personnel, including their identification with the organization, will condition the satisfaction and loyalty of customers [4]. This will also effect relations towards purchasers, suppliers and business partners.

\section{Human Potential and Motivation Accent of Personnel Work}

Human potential of an organization involves all the employees, experts and managers. It can also be defined to a large extent, as motivation, knowledge, skills, abilities, experiences and different ways of behaviour of all people within an organization. Enriching thought is that human potential consists of not only the structure and number of employees but also of aspects such as education and culture, human relations and ability to cooperate as well as to be receptive towards social and ecological factors affecting the environment, etc. [3].

Using meaningful administration of particular motivation criteria, it is possible to raise the level of experienced motivation of an organization's human potential by means of consistent motivating realisation of basic processes of management and development of human potential. This means that the focussing processes of work with human potential should be carried out with strong motivation accent so that, in this way, (even though indirectly) it can contribute to the growth of enthusiasm, satisfaction, identification and helpfulness of all members of an organizational team.

In this context it is reasonable to consider the necessity of motivation not only in large organizations, but also in smaller set-ups. Management of small and midsized organizations quite often overlook the fact that their employees have the same needs and aspirations as those workers employed in a large organization and, consequently, require the same level of motivation, perspective and education [1]. According to Brodsky [2] the main sources of motivation are needs and experience and the anomaly, which is often present, is that these feelings can have a subjective meaning for a percepted person. Therefore, the management must be aware of these individual needs of their subordinate co-workers and adjust the needs and aspirations to the overall needs of the team, department and whole workforce. We should mention here that the assertion of the motivation accent in the working process with people can lead, to a high level of fulfilment, mainly of a psychological nature, in both employees and managers within the whole of the workforce.

\section{Interviews Helping to Increase the Motivation of Human Potential}

The highest degree of motivation accent of focusing processes of management and development of human potential is most probably induced by the effective realisation of selective, orientation, appraisal and outgoing interviews. Apart from the specified prior aims, their purpose is to induce the trust of employees towards an organization, to strengthen their willingness to fully engage them-

\footnotetext{
* Martina Blašková

University of Žilina, Faculty of Management Science and Informatics, Tel. +421-41-5134455, E-mail: blaskova@fria.fri.utc.sk
} 


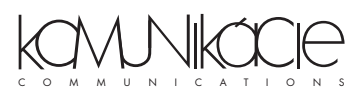

selves in particular activities that lead their behaviour to lend itself towards the achievement of an assigned vision or goal.

\subsection{Selective Interview}

The basis of the selective (admission) interview is to provide job applicants with true and sufficiently detailed information about the workplace, the organization as a socio-economic unit and, at the same time, gain an objective picture about of the real skills, abilities and personal attributes of applicants. This should be done in a form of a bilateral communication. Managers and experts from the organization should realise that this type of interview will enable them to recognise the complex potential of applicants and compare these personal competence complexes to the requirements of the position being offered to the applicant. Therefore, all the interviewers should be carried out by professionals featuring outstanding communicative skills and supportive understanding towards applicants. An objective of this interview is to create positive impression and strengthen motivation of the most suitable applicant (applicants) by enabling the applicant to accept a possible decision on being accepted for a particular job. The quality of the selective interview process mainly depends on a precise and technically well-managed preparation. In the stage of preparation, it is necessary to select the content and the form of a considered interview in advance. It is especially important to decide what information, signal, thoughts and relevant attractive images should be gained and given by both parties, i.e. interviewers and applicants. For this reason, the preparation of such an interview should come out from ongoing analyses of a considered working position, a detailed description of the job and specification of an applicant's abilities for the particular position. A thorough knowledge of all the facts based on written materials provided by the applicant is also necessary (CV, a covering letter, references, letters of application, certificates, etc.).

The applicants should prepare themselves for the interview and decide which is the most suitable (and at the same time the most honest and unstrained) method of presenting themselves. They should conduct themselves in such way that they would motivate the representative of the organization, to make the applicant the preferred choice. It is suggested that applicants should consider what the organization requires and expects from them. For example, they should pay attention to the creation of spectrum of people who have supplied evidences and information about them prior to the interview. The applicant should be well versed in areas, which highlight specific technical and administrative problems within the organization, specifically with reference to the job being offered. They should endeavour to gain as much information as is possible, concerning the organization prior to the interview.

A remarkable way to emphasise the motivation accent of selective interviews is in its initial stage - opening of the interview. The opening is the key factor, which determines the motivation shape of the interview process itself. The main idea at this level is that only in an atmosphere created by open and reciprocal trust with positive emotions (without any stress elements) it is possible to fulfil the main aims of the interview. These positive elements are: reciprocal communication, rising levels of motivation on both sides and a culmination of decisions of choice. It is known that no job interview can avoid stress and certain misgivings. Applicants as well as interviewers want to make a good impression, therefore, it is vital to focus on elimination of these negatives. Therefore, to create a motivation contact, at the start of the interview, it is preferable to cordially welcome an applicant, followed by an introduction to any organization representatives that may be present throughout the interview. It is important to inform the applicant of the format and the way in which the interview will be conducted. Conversation can be initialised by the use of some neutral topics such as weather, sport, town appearance, etc. A very positive approach can be the use of nonverbal communication - e.g. smile, handshakes, relaxed posture, showing genuine interest and leaning towards the applicant. Positive body language can be a very helpful approach in putting the applicant at ease in what could be a very stressful situation.

Subsequent stages of the interview should carry the signs of motivation emphasis. Organization representatives should be careful about asking relevant and at the same time, ethical questions. They should give the applicant sufficient time to ask his/her questions and willingly provide him/her with answers. At the termination of the interview, it is necessary to thank the applicant for showing interest, inform him/her that the organization will contact him/her to inform him/her on the results of the interview in due course. The interviewer should wish the applicant success in all of his/her future endeavours. Such "tiny" tools or wanted phrases at the final stage of the whole communication-motivational contact between applicants and organization can either reinforce the positive impression or destroy the whole effort.

\subsection{Orientation Interviews}

Orientation constitutes a specific process of management and development of human potential. It requires that the management establish an area of familiarisation of a new employee with the organization, its structure and values, as well as with working position itself and with a team of co-workers. This process encompasses efforts of involved representatives of the organization and also of the new employee himself/herself to shorten and intensify the process of getting acquainted with each other and adapting to new conditions, requirements, norms and approaches as well as expected skills related to the job to be performed.

As this process of orientation implies, a new employee will be faced with an abundance of new information, impressions, experiences, situations and confrontations, which he/she must try to manage. This period could be very stressful for a newcomer. The new recruit will encounter expectations and doubts whether he/she will successfully meet all the criteria concerning the required behaviour within the organization. Moreover, a new employee trying to become an equal member of the team may be exposed to a high degree of mental stress. That is why it is important that managers should aspire to help newcomers to integrate into a new position 
and into a new social background. Apart from well-prepared orientation programmes, an effective tool for this motivation effort from the position of a manager is the orientation interview.

When we consider the newest knowledge regarding the potential problems with management and development of human potential, it should be realised that there are three categories of orientation interviews, and these are entry (introductory), continuous (repeated) and final orientation interviews.

a) Entry (introductory) orientation interviews should open the whole process of getting to know and inure to new facts. The purpose of this interview is to get suggestions and to seek more concrete preferences and visions from a new employee about his/her work activity. In a motivational form of communication, (i.e. in a suitable pace and attractive structure) a senior manager should provide a new employee with all the relevant information dealing with his/her integration into the organization. To reinforce these factors, the manager should once again resort to a positive well-balanced use of non-verbal communication (smile, attentive gestures etc.). He should show a willingness to help at any time with occupational or social problem solving. This will result in the newcomer having a most pleasant beginning of a new phase in his/her professional life.

b) Continuous (repeated) orientation interviews should be orientated towards discussion involving facts about the organization and a given task, such as tweaking or changing and running orientation programme. This might involve answering obscure questions, problem solving issues that have been incorporated into a new working environment. These continuous interviews should be carried out with a strong motivation emphasis during the orientation period and they should be repeated. A suggested period for the realisation of continuous interviews is a minimum of two weeks, while the most suitable timescale for this motivational communication with a new employee is a period of $15-30$ minutes every week. The interval of repetition of these interviews depends on the demands of the job position, level of openness of the working team and the ability of a newcomer to absorb the amount of new information. The new employee needs to monitor the success of his/her ability to solve conflicts and complications within the organization. Throughout these debates, a manager should try to fortify the motivation of a newcomer to remain within the organization so long as no difficulties with his/her working behaviour have appeared. The manager should motivate the new employees to exert their full potential with regard to their work effort During this time, a new recruit should motivate a superior to enable him to give support even after the end of this process.

c) Final orientation interview is realised at the end of the process of orientation. It should be devoted to the total evaluation of the progress and results achieved in this orientation process. It should reflect both the views of the personnel specialist and the newly admitted (already orientated) employee. In this interview, both parties should continue in a motivation effort in the same way as in the previous interviews.

\subsection{Appraisal Interview}

Appraisal interviews are associated with highly complex methods of increasing motivation and constantly increasing quality of the complex performance of employees. They embody communication and motivational meetings during which time the superior worker discusses with an evaluated employee particular aspects of his/her working behaviour and endeavours to establish a process by which the future development of professional and personal potential of an employee is enhanced.

Consistently enforcing motivation accent of appraisal interview can consequently effect a deeper identification of an employee with the organization, to show willingness to increase systemic development of the working results of creativity and innovation, etc. In the practice of management and development of human potential, the most frequently chosen interviews fall into one of these categories: either an interview at the working performance level with negative aspects to its approach, or one with a positive approach towards working performance.

a) Motivational appraisal interview with particular defects in performance should be realised using the so-called "sandwich effect" technique. The idea is to implement in conversation negative warnings or problems that may affect the working performance between introductory positive statement about performance and final motivation appeal for a future improvement within the organisation. This means that at the beginning of the interview it is acceptable to put an employee into a positive mood by emphasising positive sides of his/her performance in an objective way. Consecutively, it is necessary, in a tactful and diplomatic manner to introduce problematic areas mentioned in an evaluative reference and give the employee the opportunity to express his/her opinion towards debated drawbacks. In a mutual discussion both the evaluator and the valuated employee should together come to an agreement upon the elimination of arisen defects and upon the identification of the most useful motivation tools, which could help to increase the degree of experienced motivation of employee in regards to remedies. When concluding the interview, the interviewer should repeatedly stress the positive merits of complex working behaviour of the employee. This will show that the organization, especially the interviewer trusts in the employee and in his potential. The interviewer should stress his willingness to help the employee in any future reparative effort required.

b) Motivational appraisal interview with a positive performance is commonly called in practise an appreciative appraisal talk. Its starting point is the knowledge that praise and appreciation are important means of accumulation of involvement, loyalty and participation of many employees and managers. In particular, the expression of appreciation and positive evaluation raises the satisfaction levels of the working effort and contributes to high levels of motivation. Opposite opinions sometimes appear pointing out to the fact that appreciative appraisals can be "dangerous". Some managers might be afraid of the fact that employees could misinterpret words of appreciation as areas of potential misuse of a situation, or even the offer of financial remuneration. However, this opinion is inaccurate, whereas 


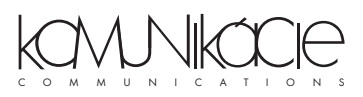

creative employees and managers (even though they do not often openly admit it) nurture the feelings of being appreciated by their superiors or colleagues. For this reason, it is very important in this type of interview, to realise that the employee believes that he/she is a valuable member of the working team and for this reason the manager should observe his/her working behaviour very positively and respect it. In this way, positively perceived appraisal conversation is a strong motivation tool for the professional as well as the non-professional future of the employee.

\subsection{Outgoing Interviews}

Outgoing interviews in combination with outgoing questionnaires can be a valuable source of important information and knowledge for the organization and its managing sections. This interview is the final and hence the most necessary form of communication and motivation meetings between the leaving employee and the direct superior manager who represents the organization.

This process can be understood as an official interview between the line manager (or a personnel department) and the employee and the manager should endeavour to find the reason why the employee chooses to leave the organisation, whilst at the same time thanking him/her for their working contributions to the organization. At this time, it is paramount that the manager should instil into the parting employee, as positive impression about the organization as is possible. Therefore, the outgoing interview should aim at motivation reinforcement of "future former" employees attitude that they would cultivate a positive image of the organization in the future.

From the point of view of systematic management and development of human potential, we can suggest the realisation of these basic types of outgoing interviews: forced leaving interview, retirement interview, resignation interview (accepted by management) and resignation interview (not accepted by management). From this group of interviews, the most problematic types of interviews are the Forced leaving interviews and Resignation interview not accepted by the management of the organization (undesirable leave).

a) Outgoing interview at forced resignation should be carried out together with the so-called "sandwich effect". Here, the managing director should explain to an outgoing employee the problems within the organization leading to the dismissal of the worker even though his work output was positive. This outgoing interview is recognised as the most unpleasant and traumatic episode of an interpersonal interview. To alleviate negative social impact of discharge it is necessary to conduct this interview with an utmost degree of sensitivity, while at the same time showing shared emotional reaction towards the dismissed employee. If it is possible or feasible, the manager should suggest ways in which the dismissed employee might renegotiate future redeployment in case the situation in organization gets better at a later date. b) Outgoing interview of undesirable leave represents a motivation interview with an employee who shows a desire to resign from the organization but the management are reluctant to lose his potential within the organization. In this situation, the role of the director or a personnel manager is to hopefully persuade the employee to reconsider his/her decision to resign his/her post. This type of interview could be deemed as being an "antioutgoing" interview, as its aim is to reverse the decision of the employee to resign from the organization. The processes and subsequent results of this type of interview depend heavily on the communication and motivation skills of the directing manager in presenting the interview in such way as to stimulate the employee to reverse his/her decision to leave the organization.

It is important to draw attention to the fact that there is a potential danger when using these types of interviewing techniques. When trying to persuade an employee not to leave the organization the management can offer him/her exceedingly attractive benefits, which cannot and would not be offered to other employees at the same level of work competence. This could result in the workforce putting pressure on the organization to compensate all staff to the same level, which would not be feasible or cost effective. That is why it is necessary to carefully consider which stimulus is from the viewpoint of the organization still effective (endurable), and, at the same time, attractive enough for the employee who intended to leave.

The success of the interview depends on the intensity of the desire of the employee not to work for the organization. If it is obvious that the employee committed in his wish to leave the organization, the "anti-outgoing" interview will be unsuccessful. Nevertheless, if the interview continues and the highly qualified and valued member of staff is still required by the organization, the manager will need to show a high degree of motivation effort, at this stage. The fact that the employee has made a choice to leave the organisation may be changed if he/she is made to question his/her motivation and loyalty towards the organization.

\section{Conclusion}

Motivation of both employees and managers is the most important and at the same time, the most difficult process of effective management and development of human potential. Its difficulties emanate from the continuity of basic systems of each motivation effort.

In certain organizations these processes of selective, orientation, appraisal and outgoing interviews can have positive effects on the quality of existing systems of work within the parameters of human potential. A supportive idea among motivated and developing employees and managers is that there will certainly be a higher tendency to remain working within the organization longer and the "turn-over" rate of staff will decrease. In this way, a long-time employment will support the growth of productivity of human potential specific for a given organization. [5]. Therefore, the motivation effort, in spite of its intensiveness, has to be a fixed component of dynamic management and development of human potential. 


\section{Acknowledgement}

This paper is supported by the grant VEGA 1/1243/04 "Highlyeducated human potential management and development". The project deals with topics aimed at the creation of basic conditions and assumptions for improvement of managerial activities in areas of highly-educated human potential development. In 2004 - 2005 the project analyses outcomes of ongoing "peaks" and "troughs" of universal models of currently educated human potential. In 2005 - 2006 the project will identify specific conditions and processes of human potential, typical for unique surroundings characterised by the superiority of higher education, and achieved scientific rep- utation and degrees. The project aims at elaboration of a model of higher educated human potential development and will focus on the creation of appertaining apparatus from the point of view of system, situation and multidisciplinary approach.

An objective of our next paper (December 2005) is to collect evidence drawn from a pre-planned and researched questionnaire involving issues relating to interpersonal skill and motivation of higher educated managers and employees from Slovakian, Czech, Polish and French universities.

\section{References}

[1] BEDNǍ̌íKOVÁ, M.: Human Resource Management at Small and Middle Firms (in Czech). In: Zborník medzinárodnej vedeckej konferencie Manažment ludského potenciálu v podniku. Zvolen, Technická univerzita vo Zvolene, 2004, str. 57-60. ISBN 80-2281330-3.

[2] BRODSKÝ, Z:: Comparison of Management Motivation in Public Administration and Enterprises. In: Zborník medzinárodnej vedeckej konferencie Manažment ludského potenciálu v podniku. Zvolen, Technická univerzita vo Zvolene, 2004, str. 285-287. ISBN 80-2281330-3

[3] HITKA, M.: Analysis of Motivation Factors of Employees of Maintenance Department at v ZSNP Foundry, a. s. Žiar nad Hronom (in Slovak). In: Zborník medzinárodnej vedeckej konferencie Manažment ludského potenciálu v podniku. Zvolen, Technická univerzita vo Zvolene, 2004, str. 189-196. ISBN 80-228-1330-3

[4] JANKAL, R.: Tri*M - The Customer Retention System. In: Journal of Information, Control and Management Systems 1/2003. Žilina, Žilinská univerzita, FRI. EDIS, 2003, str. 39-46. ISSN 1336-1716

[5] KUCHARČÍKOVÁ, A., VODÁK, J.: Present Look at Future of Tomorrow. New Look at Skill and Abilities of Employees - Human Capital (in Slovak). In: Produktivita č. 6/2002, str. 15-17. ISSN 1335-5961. 